\title{
EDUCATION OF TECHNICAL SUBJECTS SUPPORTED BY CAX APPLICATIONS
}

\section{Karel DVO $\breve{R} A K$}

\begin{abstract}
CAx (CAD, CAE, CAM) technologies represent progressive tools for technical production planning. Didactic potential of these applications for teaching of professional technical engineering oriented subjects can be utilized in education. Teaching supported by the use of this category of information technologies is the way how to improve knowledge and skills of students of technical specializations.
\end{abstract}

Key words: design, engineering, manufacturing, virtual prototype, 3D data model, assembly

\section{VÝUKA TECHNICKÝCH PŘEDMĚTŮ, PODPOROVANÁ CAX APLIKACEMI}

Resumé: $\mathrm{CAx}(\mathrm{CAD}, \mathrm{CAE}, \mathrm{CAM})$ technologie představují progresivní nástroje pro technickou př́ípravu výroby v průmyslové praxi. Ve vzdělávání lze uplatnit didaktický potenciál těchto aplikací pro výuku odborných technických strojírensky orientovaných předmětů. Výuka podporovaná využitím této kategorie informačních technologií je cestou ke zvýšení znalostí a dovedností posluchačů technických oborů.

Klíčová slova: konstrukce, strojírenství, výroba, virtuální prototyp, 3D datový model, sestava

\section{1 Úvod}

CAx technologie představují portfolio aplikací pro podporu inženýrských činností, zaměřených především na návrh konstrukčních řešení dílů a sestav, ověřování funkčnosti konstrukcí a stanovení technologie výroby nebo montáže. Základními nástroji v této kategorii informačních technologií jsou:

- CAD - Computer Aided Design, tvorba datových 3D modelů a 2D výkresové dokumentace.

- CAE - Computer Aided Engineering, simulace a analýzy na modelech vytvořených $\mathrm{v}$ CAD.

- CAM - Computer Aided Manufacturing, tvorba technologie, obvykle postupu obrábění na $3 \mathrm{D}$, nebo $2 \mathrm{D}$ datovém modelu výrobku.

- PLM - Product Lifecycle Management system, filozofie správy konstrukčních dat a rrízení procesů spojených s životním cyklem produktu.

$\mathrm{V}$ textu budou představeny a uvažovány postupy na 3D datových modelech (Fořt, Kletečka, 2007). Současný trend průmyslové praxe, technologické možnosti IT vybavení a dispozice nastupující generace techniků vyžadují vytvoření souladu s výukovými metodami v procesu vzdělávání (Rabe, Šlégr, 2010). Aktuální stav vyžaduje stále širší uplatňování postupů, využívajících digitální 3D reprezentaci výrobků ve virtuálním prostředí. Vhodně naplánovaná výuka na projektech virtuálních prototypů by měla vést k posílení mezipředmětových vztahů a ke zvýšení znalostí a dovedností odpovídajících profilu absolventa př́islušného strojírenského oboru.

\section{Virtuální prototypy}

Soubory digitálních dat představují modely komponent a sestav, na kterých lze prostřednictvím vhodných $\mathrm{CAx}$ nástrojů uplatňovat široké spektrum činností $\mathrm{k}$ prověření kvality a funkčnosti návrhu (Fořt, 2010). Provedené analýzy modelů umožňují efektivněji pochopit chování konkrétních konstrukčních řešení a jejich variant. Jde zejména o následující postupy:

- Vlastní tvorba 3D modelů.

- Skládání sestav z komponent.

- Vizualizace modelů nebo sestav.

- Kinematická analýza mechanismů.

- Pevnostní kontrola namáhaných dílů.

- Prostorové posouzení prvků.

- Měření a analýzy modelů a sestav.

- Návrh a ověření technologie výroby.

- Návrh a ověření technologie montáže.

$\mathrm{V}$ průmyslové praxi spočívá př́nos uvedených aktivit zejména ve zkrácení doby potřebné pro konstrukci a technickou prípravu výroby. Významné je také současné snížení nákladů na materiál, logistiku a výrobu reálného prototypu. 
Další prrínos je např. zefektivní procesu změnového řízení pro fázi vývoje a zkoušek reálného prototypu, nebo provedení úprav pro dokončený produkt.

Ve školním prostředí lze díky zmíněným vlastnostem virtuálních prototypů $\mathrm{v}$ přiměřeném rozsahu realizovat všechny uvedené postupy. Žáci mohou nejen navrhovat, ale i provádět simulace provozu na svých projektech, což by bylo reálně vzhledem $\mathrm{k}$ vysokým nákladům často nemožné. Výstupy projektů jsou navíc přenositelné, prezentovatelné, je snadná jejich archivace a případné použití $\mathrm{v}$ následné pokračující výuce.

\section{Dostupnost CAx technologií}

Nezbytným faktorem pro realizaci představené koncepce je dostupnost vhodné 3D CAx aplikace, která disponuje dostatečným portfoliem funkcí uplatňovaných při řešení projektu.

CAx aplikace používané $\mathrm{v}$ průmyslové praxi jsou obecně velmi nákladné. I v současné době, kdy trh nabízí velké množství konkurenčních produktů, představuje jedna kompletní instalace náklady srovnatelné s hardwarovým vybavením celé počítačové učebny školy. Součástí obchodní strategie většiny dodavatelů této kategorie softwaru je zpřístupnění využití ve vzdělávacím sektoru $\mathrm{s}$ přihlédnutím $\mathrm{k}$ materiálovým možnostem škol. Existují akademické licence, plně funkční a za symbolickou cenu. Často je možnost instalace na domácích počítačích posluchačů a pedagogů. Tento významný fakt dává žákům prostor pro samostatnou tvorbu a vzdělávání se mimo školní vyučování. Pedagogům umožňuje průběžnou práci na zadávání, optimalizaci a vyhodnocování žákovských prací. Náklady na akademické licence mohou být součástí grantových programů nebo se na nich mohou podílet průmyslové podniky $\mathrm{V}$ regionu školy. $\mathrm{V}$ těchto firmách posluchači a absolventi často nacházejí profesní uplatnění. Finanční hledisko tedy nepředstavuje překážku využití této kategorie softwaru ve výuce.

\section{Výuka, podporovaná CAx aplikacemi}

Cílem projektově orientované výuky, podporované využitím CAx aplikací, je zvýšení znalostí a zlepšení dovedností posluchačů v předmětech, daných studijním plánem oboru a $\mathrm{s}$ tím související uplatnitelnost absolventů v profesní praxi. Teoretické základy získané při „klasickém“ v jednotlivých předmětech jsou uplatněny při návrhu konstrukčních a technologických řešení $\mathrm{v}$ průběhu práce na projektu (Dvořák, 2011). Východisky jsou znalosti z předmětů:

- Strojnictví.

- Strojírenská technologie.

- Technologie montáží.

- Technologie specializace oboru.

- Stroje a zařízení.

- Konstrukce nářadí a př́ípravků.

- Technická dokumentace.

- Mechanika, pružnost a pevnost.

- Informační a komunikační technologie.

- Základy CAD, CAE, CAM.

Příkladem středně náročného projektu může být komplexní zadání návrhu a technologie výroby ozubeného kola. Ozubené kolo je obráběné z předlitého polotovaru - odlitku. Pro výrobu odlitku je třeba navrhnout nástroj, v tomto prrípadě dutinu formy, rozdělenou dělící rovinou. Př́iklad modelu základních komponent v CAD je na obrázku č. 1 .

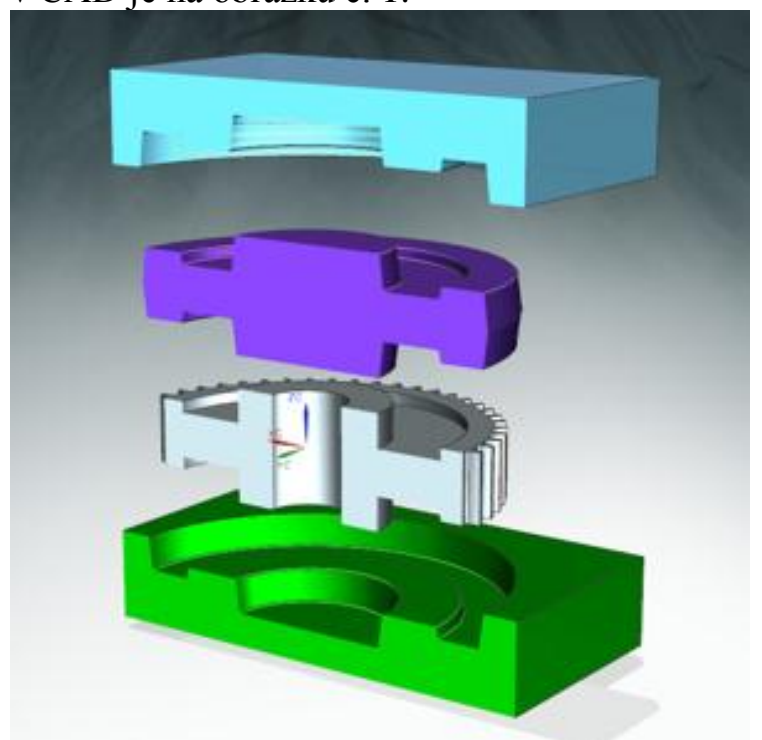

Obr 1: CAD sestava základnich komponent technologického procesu výroby ozubeného kola

Ozubené kolo se navrhne v souladu s pravidly konstruování. Dle tvarové složitosti, rozměrů a požadavku „předlití“ některých konstrukčních prvků se navrhne model odlitku - díl nad ozubeným kolem. Tvar a rozměry odlitku jsou asociativní s výsledným produktem. 3D data modelu odlitku jsou výchozí geometrií pro zhotovení dutiny formy, rozdělené $\mathrm{v}$ dělicí rovině - spodní a horní díl. Dle požadovaného rozsahu projektu lze ještě zařadit např. pevnostní kontrolu komponenty v sestavě, simulaci lití a tvorbu 
technické dokumentace komponenty a formy. $\mathrm{Na}$ popsaném príkladu lze představit, popsat a uplatnit postupy zahrnuté $\mathrm{v}$ tematických plánech vztažených technologických předmětů, vyučovaných na středních odborných školách a vyšších odborných školách strojírenského zaměření. Ve výčtu předmětů jsou uvedeny základní předměty a některé specializované předměty, např. základy ovládání $\mathrm{CAD}$ aplikace. Řešení a postupy uplatněné posluchači při práci na projektu by měly vycházet $\mathrm{z}$ teoretických znalostí a být v souladu se zásadami technické normalizace. Nová, netradiční řešení musí být technologicky zdůvodnitelná (Střelec, 2010). Pedagog $\mathrm{v}$ průběhu výuky plní roli koordinátora, konzultanta a provádí průběžné, resp. finální hodnocení projektu.

\section{Struktura zadávaných projektů}

Zadávané projekty by měly vykazovat několik charakteristických prvků, které určují okruh cílových znalostí a dovedností posluchačů a to i v př́padě, že si téma projektu volí jednotlivec, nebo řešitelský tým sám. $\mathrm{V}$ príípadě, že projekt má být řešen týmově, se osvědčila práce ve tříčlenných skupinách. Příkladem vypracovávaného projektu může být konstrukční řešení detailu, např. části dopravního prostředku, sportovního zařizení, modelářského výrobku, ručního nářadí apod.

Jedním z kritérií při zadávání projektu je modelovací složitost jednotlivých komponent. Je vhodné umožnit posluchačům práci na projektu zvoleného dle oblasti jejich zájmu, zadání však musí být korigováno pedagogem tak, aby byla splněna určitá kritéria. Těmito kritérii jsou:

- Rozsah předpokládaných prací na projektu odvíjí se od přiděleného času, počtu členů týmu a je určen predevším počtem komponent.

- Složitost modelovaných dílů.

- Rozsah předpokládaných výpočtů a simulací.

- Náročnost navrhované technologie výroby.

- Požadavek kompletní výrobní dokumentace.

Projekt nesmí být co do rozsahu a složitosti př́liš triviální. Tato skutečnost znamená nevyužití přiděleného času a vede ke snížení celkové efektivity výuky uplatňovanou metodou.

Naopak v př́ípadě rozsáhlého projektu vzniká nebezpečí, že projekt nebude dokončen. Nedokončení projektu bývá i důsledkem nevhodné organizace činností $\mathrm{v}$ průběhu projektu, daná malou zkušeností posluchačů. Úlohou pedagoga ve fázi zadání je usměrnění představ posluchače do realizovatelných mezí při dodržení stanovených kritérií a respektování vytyčeného cíle. Je důležité vzít $\mathrm{v}$ úvahu skutečnost, že $\mathrm{z}$ objektivních důvodů nedokončený projekt může být považován za splněný a může být pozitivně hodnocen.

\section{Hodnocení žákovských projektů}

Ke správně dokončenému projektu vede obvykle několik různých cest. Ze zvolené metody modelování lze posoudit dovednosti a schopnosti pracovat $\mathrm{s}$ použitou CAD aplikací a diagnostikovat další schopnosti pro řešení dané strojírenské úlohy a identifikovat strategické myšlení žáků. Na použité strategii často závisí efektivní tvorba technologického postupu výroby reálného produktu. Účelem hodnocení projektů není jenom klasifikace, ale především zpětná vazba pro posluchače a pedagoga. Hodnocení projektů, resp. jejich řešitelů je třeba rozdělit do dvou fází.

První fází je průběžné hodnocení na základě pozorování žáků a kontroly stavu rozpracovaných projektů. Zde se hodnotí především aktivita a prístup posluchače $\mathrm{k}$ řešení úloh spojených s projektem. Posuzuje se zdokonalování ve využívání CAx aplikace, práce $\mathrm{s}$ informačními zdroji a dodržování termínového plánu projektu.

Druhou fází je analýza dat dokončeného projektu. Zde se hodnotí celkové dodržení předem stanovených kritérií, dodržování technických norem, obecných pravidel konstruování a tvorby technologických postupů.

$\mathrm{V}$ obou fázích hodnocení je třeba vést $\mathrm{s}$ posluchačem rozpravu nad posuzovanými prvky.

Součástí hodnocení je i posouzení tvořivosti jednotlivých řešitelů projektu a zvlášt' identifikace vynikajících řešení.

\section{Výukové materiály pro posluchače}

Zejména $\mathrm{v}$ prvních fázích práce na projektech je vhodné dát posluchačům k dispozici komplexní výukový materiál na bázi prŕručky, ve které jsou stručně představeny základní kroky práce na projektech, ale také možné problematické postupy $\mathrm{v}$ použité $\mathrm{CAx}$ aplikaci. $\mathrm{Na}$ základě výzkumu, zaměřeného mimo jiné na postoje žáků $\mathrm{k}$ výuce podporované CAx aplikacemi lze pozorovat nedostatek studijních materiálů pro samostatnou práci na projektech. Tento problém se týká i výuky práce s použitým CAx nástrojem (Soták, Kuník, \& 
Soták, 2010). Informační zdroj $\mathrm{v}$ první řadě posluchačům usnadní zahájení práce a může kompenzovat obvykle nízkou časovou dotaci pro předmět a pro koordinovanou činnost. Přesto, že i různé projekty by měly vykazovat společné specifické rysy, pestrost zadání s sebou často přinese možnost netradičních a nových postupů. Nové přístupy ke specifickým řešením tak mohou být $\mathrm{v}$ otevřených výukových materiálech zaznamenány a využity při řešení následných projektů. Manuál by měl obsahovat minimálně následující blíže popsané body:

- Základní kritéria struktury projektu.

- Metodiku tvorby časového plánu.

- Doporučení rozdělení aktivit v týmu.

- Organizaci a zabezpečení veškerých dat a informací souvisejících s projektem.

- Odkazy na dostupné informační zdroje.

- Základní postupy zakládání datových souborů v použité CAx aplikaci.

- Jmenné konvence vytvářených CAD souborů komponent a sestav.

- Doporučení pro zakládání souborů s 2D výkresovou dokumentací.

- Postupy připojování negeometrických informací - atributů $\mathrm{k}$ datovým modelům

- Návod pro definování zatížení a okrajových podmínek pro pevnostní kontrolu součásti

- Návod pro provádění měření a výpočtů na geometrii modelů.

- Postupy pro tvorbu závěrečných zpráv provedených analýz a simulací.

- Prezentace a distribuce kompletní dokumentace dokončeného projektu.

- Proces změnového řízení na modelech ve fázi návrhu.

Vedle výše uvedených doporučení je vhodné připojit popis nejčastěji používaných složitějších funkcí a postupů specifických pro použitý $\mathrm{CAx}$ nástroj.

\section{Manuál pro učitele - konzultanty projektů}

Vedle komplexního výukového materiálu pro posluchače je velice důležité, aby pedagog, který zde plní především roli koordinátora a konzultanta projektu, měl $\mathrm{k}$ dispozici vlastní materiály, obsahující doporučení a pravidla, která je vhodné $\mathrm{v}$ průběhu koordinace žákovských projektů dodržet. $\mathrm{V}$ ideálním př́padě by měly vycházet $\mathrm{z}$ materiálů pro posluchače, rozšsiřených o následující témata:

- Postupy a kritéria pro určení, zda zadávaný projekt je dostatečný.

- Kritéria hodnocení záměru projektu.
- Hodnocení průběžného stavu projektu vzhledem $\mathrm{k}$ zadání a požadovaným kritériím.

- Posouzení souladu s termínovým plánem projektu.

- Vyhodnocení dokončeného projektu z hlediska provedení návrhu.

- Hodnocení posluchačů dle komplexního prístupu a aktivity.

- Vyhodnocení efektivity použité metody výuky.

Uvedené body jsou především doporučení a úloha pedagoga spočívá $\mathrm{v}$ rozšíření a zahrnutí vlastních metod dle aktuální situace ve skupině posluchačů a plánovaného rozsahu projektu.

\section{Výzkum efektivity výuky}

Výuka odborných technických, strojírensky orientovaných predmětů na projektech virtuálních prototypů, podporovaná využitím CAx aplikací vede ke zvýšení znalostí a dovedností posluchačů. Přijetí, nebo zamítnutí této hypotézy a optimalizace didaktického systému je předmětem probíhajícího výzkumu, zaměřeného nejen na měření výkonů posluchačů, ale také na jejich postoje $\mathrm{k}$ využívaným technologiím a metodám výuky (Melezinek, 1994). Proces vyžaduje komplexní posouzení problému $\mathrm{z}$ hlediska technické báze škol, kvalifikace pedagogů, kompetencí a postojů posluchačů $\mathrm{k}$ využívání informačních technologií, zejména CAx aplikací. V realizaci výzkumu je uplatněna smíšená metodologie $\mathrm{s}$ převažujícím kvalitativním šetřením. Výzkum probíhá při výuce předmětů CAD a ICT ve strojírenství, které jsou součástí studijních plánů oboru Informační technologie ve strojírenství na vyšší odborné škole. Kvalitativní zkoumání je založeno na pozorování postupů jednotlivců při práci na projektech a analýze výsledků dokončených projektů posluchačů. Parametrem jsou dovednosti posluchačů a schopnosti řešit samostatně úlohy strojírenské konstrukční praxe. Kvantitativní zkoumání vychází ze statistického zjišt’ování postoje posluchačů technických škol k CAx technologiím a jejich motivace pro studium oboru. Zároveň jsou vyhodnocovány testy obecných znalostí CAx a strojírenství. Výsledky testů jsou statisticky zpracovány a slouži k upřesnění

závěrů z kvalitativních fází výzkumu. První část výzkumu proběhla na skupině posluchačů čtvrtého ročníku SPŠ a skupině posluchačů druhého ročníku VOŠ. Výzkum pokračuje na žákovských projektech posluchačů druhého a 
třetího ročníku VOŠ ve Žd’áru nad Sázavou, kde má výuka CAx technologií mnohaletou tradici, škola disponuje kvalitní technologickou bází a spolupracuje se strojírenskými podniky v regionu.

$\mathrm{V}$ době zveřejnění př́spěvku probíhá zpracování a vyhodnocování získaných dat. Bližší popis průběhu výzkumu, vyhodnocení, závěry a zjištění mohou být publikovány $\mathrm{v}$ některém $\mathrm{z}$ následujících př́íspěvků.

\section{Závěr}

Systematické využívání 3D CAx aplikací ve vyučování odborných technických předmětů je cestou ke zvýšení efektivity výuky. Uplatňovaný př́stup odpovídá trendu informatických znalostí a dovedností současné generace potenciálních techniků. Schopnost orientovat se v postupech řešení konstrukčních, simulačních a technologických úloh je požadavkem průmyslové praxe. Pro pedagogy je zde př́ležitost odborného růstu a uplatnění vlastní tvořivosti při př́ípravě a koordinaci projektů. CAx aplikace lze vedle strojírenských řešení využít i pro úlohy ve stavebnictví, elektrotechnice a dalších příbuzných oborech. Řada specializovaných modulů tyto nástroje rozšiřují o funkce a postupy pro řešení konkrétních úloh. Možnost vytvořit vlastní nástroje ve formě maker a knihoven dalších funkcí vyžaduje důkladnou znalost systému a často i programátorské zkušenosti, nicméně může být předmětem dalšího zkoumání a bádání motivovaných posluchačů informaticky zaměřených oborů. Další možností je využití pro podporu výuky vybraných témat př́rodovědných předmětů, kde lze uplatnit modelovací, vizualizační, nebo simulační potenciál CAx aplikací. Typickými prŕklady jsou úlohy mechaniky nebo optiky ve fyzice, analytické a konstruktivní geometrie v prostoru, návrh elektronických prvků a logické úlohy. Tyto oblasti mohou být $\mathrm{v}$ budoucnu předmětem dalších experimentů a výzkumů.
Příspěvek vznikl za podpory projektu specifického výzkumu PdF UHK 2011 Počítačová podpora výuky odborných technických předmětů

\section{Literatura}

[1] FOŘT, P. - KLETEČKA, J. Autodesk Inventor : Funkčni navrhování v průmyslové praxi. Brno : Computer Press, 2007. ISBN 97880-251-1773-6.

[2] RABE, V. - ŠLÉGR, J. Využití ICT ve výuce prírodovědných disciplín. Journal of Technology and Information Education. 2010, Olomouc EU, Univerzita Palackého, Ročník 2, Číslo 2, s. 13 - 15. ISSN 1803-537X (print). ISSN 18036805 (on-line).

[3] FOŘT, P. Řešení žákovských projektů pomocí PLM technologii. Brno, 2010. 56 s. Závěrečná práce. Mendelova univerzita $\mathrm{v}$ Brně, Institut celoživotního vzdělávání.

[4] DVOŘÁK, K. Projektově orientovaná výuka, podpořená strategií PLM. IT CAD, 2011, 21, 1, s. 36-37.

Dostupné

$<$ http://www.cad.cz/home/casopis-itcad.html?rocnik=2011\&id=82>

[5] STŘELEC, M. CAE technologie $v$ protetickém vývoji. 2010. 62 s. Absolventská práce. VOŠ a SPŠ Žd'ár nad Sázavou.

[6] SOTÁK, J. - KUNÍK, M - SOTÁK, R. Systémy CAD/CAM vo vyučovaní na SPŠ strojárskych. Journal of Technology and Information Education. 2010, Olomouc - EU, Univerzita Palackého, Ročník 2, Č́́slo 2, s. 51 54. ISSN 1803-537X (print). ISSN 1803-6805 (on-line).

[7] MELEZINEK, A. Inženýrská pedagogika. ČVUT Praha, 1994. ISBN 80-01-00672-4.
Ing. Bc. Karel Dvořák
Univerzita Hradec Králové
Pedagogická fakulta
Rokitanského 62
50003 Hradec Králové
Tel.: +420 603319305
e-mail: karel.dvorak@uhk.cz 